\section{Networks in the United States}

\section{Washington}

THE US government will need to double its current spending on high-performance computing if it is to retain strength and leadership in that area for the forthcoming decades. That is the conclusion of a report requested by Congress and prepared by an interagency committee of the government. The government now spends some $\$ 500$ million per year supporting research and development in computer hardware, software and networking capabilities.

Although market forces will push commercial development of computing capacity, resources that can meet the special computing needs of fundamental scientific and engineering research will require a "shared vision" among government, industry and higher education for the proper allocation of resources.

The new report was written by three subcommittees of the Federal Coordinating Council on Science, Engineering and Technology (FCCSET) committee on computer research and applications, whose membership included federal agencies with interest in computing activities. Paul Huray of the University of Tennessee, who chaired the FCCSET committee, says the report represents a first step in reaching that shared vision.

The FCCSET report was originally intended to address only computer networking, but Huray says the committee felt that overemphasis on networking might obscure needs in other areas of computing. In hardware, the report urges a long-range strategy for federal support for basic research, and improved mechanisms for transferring government-sponsored technology into the private sector.

At a time when the White House has been looking for ways to trim the federal deficit, it is notable that the FCCSET report, reviewed at the highest levels of the White House, calls for increased federal spending. The report recommends an immediate doubling of the $\$ 50$ million spent annually on networking, with an incremental rise in federal spending on other areas of advanced computing leading to a doubling of current spending in five years.

The 29-page FCCSET report, originally a much larger document, deals only briefly with issues that are sure to be contentious. Who should pay for using the research network? What government agencies should be in charge of supporting basic research? How should government help industry to compete in global markets? Huray says the FCCSET report is intended to stir up those questions, rather than suggest formal answers.

Joseph Palca

Doubts about customers for planned Japanese network system

\section{Tokyo}

NiPPON Telegraph and Telephone (NTT), Japan's giant domestic telecommunications company, is pressing on with plans to introduce a commercial digital Information Network System (INS) linking Tokyo, Osaka and Nagoya by early next year. But the results of a trial in Tokyo suggests that there will not be a flood of INS subscribers.

In September 1984, NTT began an ambitious experiment to test a model INS in the Mitaka suburb of Tokyo. About 2,000 subscribers (both household and business users) participated in the twoand-a-half year project which cost $¥ 20,000$ million ( $\$ 150$ million).

The idea of INS is to link telephone, telex, facsimile, teletext, computers and video transmission to one communications network. Mitaka subscribers were allowed to test out all the latest electronic gadgetry, including videophones, sketchphones, high-speed digital facsimiles and the CAPTAIN videotext system.

But customer reaction to the new information age is mixed. Although high marks were awarded by companies to videophones, video conferences and highspeed facsimile machines, housewives complained that their high-speed faxes were inundated with junk mail from local supermarkets (see below). CAPTAIN terminals were too difficult for some of the general public to operate and users had to wade their way through pages of uninteresting information on the screen - a common criticism which will only be overcome when much more sophisticated software is developed. And Nobuo Inoue, executive director of NTT's research and development headquarters, admits that he has "no idea" how to deal with the problem of "information overload".

NTT is nevetheless pressing ahead. A larger field experiment covering Tokyo, Osaka, Nagoya and the academic city of Tsukuba has already begun with the participation of 20 private companies. And NTT plans to convert the system to a commercial service in March 1988.

According to Inoue, one of the most popular experiments in Mitaka involved the link-up of satellite offices in the suburb with main offices in the downtown area of Tokyo. A branch office of NEC, the electronics giant, and a printing company with a printing works in the suburb found that by using a videolink, employees could avoid shuttling back and forth between the main and satellite office. If such a system could help ease the congestion of Tokyo's overcrowded commuter trains it would certainly be welcome.

Broadband videolinks, however, are still far too expensive to contemplate. But NTT has developed a second system that can transmit real-time pictures, provided the conference participants do not move around too much. And Inoue thinks this is commercially viable.

So how much will INS cost the subscriber? NTT is negotiating with the Ministry of Posts and Telecommunications. NTT officials admit that nobody has a clear idea of what would be an appropriate tariff system - a "political decision" is required, they say. But NTT expects that, at least to begin with, INS will be four or five times as expensive as the present telephone network.

Judging from the reaction of the general public in Mitaka, it seems safe to conclude that for the next several years INS use will be confined to corporation that can afford to pay the bill.

David Swinbanks

\title{
Direct mail ordeal by facsimile machine
}

\section{Tokyo}

JUNK mail by telefax? The information age has arrived in Japan with a vengeance. NTT's trial of an Information Network System in a suburb of Tokyo had one unexpected result: housewives were deluged with unsolicited promotional material received on high-speed facsimile machines installed in their homes. This new form of direct mailing threatens to become a major nuisance for facsimile owners - and there are now 1.5 million machines in Japan.

The very high postal charges in Japan make this new form of direct mail particularly attractive, and direct mailers are not the only ones to see the potential of facsimile machines. Some pranksters dial up facsimile machines at night and feed a continuous loop of paper into their machine with indecent or abusive words written on it. The next morning the unfortunate recipient finds his facsimile emptied of paper and the floor strewn with messages. As a continuous loop is used there is no record of the sender.

How can facsimile owners be protected? Dr Nobuo Inoue, executive manager of NTT research and development headquarters, says that facsimiles could be programmed to receive only from specified numbers. A more practical solution may be to design facsimile machines that can initially store messages electronically and display them on a screen. The recipient could then print out only selected material. David Swinbanks 